TAPROBANICA, ISSN 1800-427X. November, 2020. Vol. 09, No. 02: pp. 217-219, pl. 58-59.

(C) Research Center for Climate Change and Department of Biology, Faculty of Mathematics \& Natural Sciences, University of Indonesia, Depok 16424, INDONESIA.

http://www.taprobanica.org/

https://doi.org/10.47605/tapro.v9i2.234

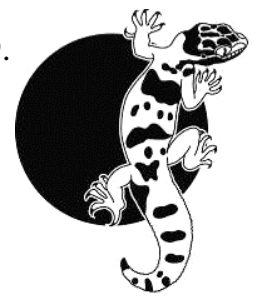

\section{Range extension of a globally endangered Martenstyn's barb, Systomus martenstyni}

Sri Lanka is endowed with a rich network of rivers that dissects the island into 103 river basins. Mahaweli River, $332 \mathrm{~km}$ long, is the largest of these basins, covering $10,327 \mathrm{~km}^{2}$, approximately one-sixth of the island's land area. Mahaweli River passes through three bioclimatic zones and therefore comprises a cross-section of almost all the natural ecosystems present in Sri Lanka other than tropical rainforest. Further, the river basin is inhabited by a diverse species assemblage including a number of endemic plants, fish, frogs, reptiles and mammals that are restricted to this river basin. Martenstyn's Barb Systomus martenstyni (Sinhala name: Dumbara Pethia) is one such endemic freshwater fish species restricted to the Mahaweli Basin.

Systomus martenstyni is endemic to Sri Lanka and is listed as a globally and nationally endangered species (Fernando et al. 2019, Goonatilake et al. 2020) due to habitat loss, fragmentation, drought, and as it has a restricted distribution within the Mahaweli River Basin. Systomus martenstyni can be easily distinguished from other species belonging to genus Systomus by the presence of a prominent, elliptical black blotch on the caudal peduncle; the body of the fish is golden in colour; all fins are deep red in colour and darker towards the ends; $27-30+2-3$ scales along lateral line; 9-12 (modally 11) pre dorsal scales; two pairs of barbels (Pethiyagoda 1991). Systomus martenstyni was initially described as Puntius martenstyni by Pethiyagoda (1991) based on a specimen collected from Pallegama at Kalu Ganga [not Kalu River], a tributary of Amban River, which is one of the main tributaries of Mahaweli River. Pethiyagoda et al. (2012) carried out a taxonomic revision of the genus Puntius and referred this species to genus Systomus. Until 2015, the species was recorded only from tributaries of Amban River such as
Kalu Ganga, Sudu Ganga, Kambarawa Oya and its two tributaries, Theligam Oya and Puwakpitiya Oya at elevations $150-500 \mathrm{~m}$ a.s.l. (Goonatilake 2012; Goonatilake et al. 2020). All of these streams drain the northern slopes of the Knuckles mountain range. More recently, Rajakaruna et al. (2015) identified two more populations of $S$. martenstyni from the lower reaches of Loggal Oya and Badulu Oya, which are also two major tributaries of the Mahaweli River. Both of these rivers drain the Southeastern basin of the Mahaweli River.

A significant part of its habitat was to be affected by the construction of two large reservoirs, namely Moragahakanda and Kaluganga on Amban River and Kalu Ganga that were commissioned in 2015. As a mitigation measure, IUCN Sri Lanka was given the task of translocating the population in the affected stretches of Amban River and Kalu Ganga into safe sites in the upper catchment of the two reservoirs (IUCN-SL 2012). During this period, spanning Jan 2012 to Dec 2013 altogether 484 individuals of $S$. martenstyni were translocated to safe sites in the upper catchment of Puwakpitiya Oya and Kalu rivers. During the translocation it became clear that the population size of $S$. martenstyni is larger than was assumed, even though the exact population size is not known at present. Further, during the last five years it has been recorded from a number of new localities (De Silva et. al. 2015, Rajakaruna et al. 2015). Therefore the number of known localities has increased its extent of occurrence $\left(\mathrm{EOO}=2,410 \mathrm{~km}^{2}\right)$ and area of occupancy $\left(\mathrm{AOO}=156 \mathrm{~km}^{2}\right)$ of the species.

Here we report a new location of $S$. martenstyni that was discovered while conducting a survey for another freshwater fish Labeo fisheri that is restricted to the Mahaweli basin. In this study, identification was carried out with the aid of the key characters introduced by Pethiyagoda (1991). This species identification was done onsite based on the following characters that are unique to $S$. martenstyni: all fins are deep red in colour and 
darker towards the ends; the body is a golden colour; and there is a prominent elliptical black blotch on the caudal peduncle (Fig. 1). The fish was studied through visual observations from the stream banks and by snorkeling in the deep sections of the streams. This new location is from the Hulu Ganga, another major tributary of Mahaweli River. Hulu Ganga is a southward flowing river that originates from the southern slopes of Knuckles Mountain range and drains into the Victoria Reservoir. The new site is located close to Giddawa Village (Fig. 2), at an elevation of $560 \mathrm{~m}$, which is the highest elevation from which this fish has been recorded to date. All the previous records are confined to elevations $150-500 \mathrm{~m}$ a.s.l. The previous elevation records from Badulu Oya and Loggl Oya were at 84-101 $\mathrm{m}$ a.s.l. Further, the new locality is found at a point above the Victoria Dam. This new location is situated in the intermediate zone of the island where the mean temperature is $\sim 25^{\circ} \mathrm{C}$ with a maximum temperature $\sim 29^{\circ}-32^{\circ} \mathrm{C}$. Annual rainfall received by the Hulu Ganga catchment is around 1,375 mm (MPE-SL 2009).

A population of around 15 to 20 individuals was identified at the locality and the population was comprised completely of adult fish. The sections of the stream where the fish was observed had clear, well oxygenated water with a rocky or sandy substratum. The fish were observed in both shady and open sections of the river. However, the fish showed a preference for rocky pools. The new location in which this species has been identified had similar habitat characteristics to other sites where the fish has been recorded. Shaded regions result from the growth of tall trees on the riverbanks. The presence of rock outcrops in the riverbed leads to the formation of rock pools, which have been described as the ideal and preferred habitat of this fish by previous authors (Pethiyagoda 1991, De Silva et. al. 2015, Rajakaruna et al. 2015). The river section of the Hulu Ganga from which the fish was recorded was wide as in the case of previous known locations. A continuous and slow flow of water was observed but the water on the rock outcrops suggest that high flows exist in this river during the monsoon season, which was confirmed by local inhabitants. The other freshwater fish species recorded at the site include: Channa kelaartii, Dawkinsia filamantosa, Devario malabaricus, Garra ceylonensis, Puntius bimaculatus, Rasbora dandia, Tor khudree, Heteropneustes fossilis and Poecilia reticulata.

The fact that this population was found above the Victoria Dam means that the habitat available is highly restricted. The presence of the dam also prevents the downward migration of this fish and therefore the population can be considered to be an isolated sub-population. Further, there are several mini-hydro projects located in Hulu Ganga that result in further habitat fragmentation. Since the catchment of the Hulu Ganga does not contain any protected areas and most of the lands on the riverbank are privately owned the chance of disturbance to the river is very high. Moreover, a number of illegal activities such as unsustainable fishing using dynamite or poison and illegal sand mining were also observed in this river section during the field investigation. Dynamite fishing or poisoning results in indiscriminate killing that wipes out large numbers of fish, while sand mining causes extensive damage to riverbeds and alters the habitat characteristics. These threats may have a significant impact on this small fragmented population that will heighten the risk of its extirpation from this site. Identification of overall distribution (Fig. 3) and habitat characteristics of threatened endemic fish species is a vital step that will facilitate proper assessment of the threat status as well as to develop sound recovery plans for such threatened endemic species. Therefore, identification of this new location while improving the available data on this fish, also highlights the need to take urgent conservation action to protect this species as most of its habitats are under severe threat due to ongoing developmental activities as well as other illegal activities.

\section{Acknowledgements}

We thank Ananda Mallawatantri (Country Representative, IUCN Sri Lanka) and Shamen Vidanage (former Programme Coordinator, IUCN) for their guidance and support during the project. Darshani Wijesinghe (IUCN Sri Lanka) is acknowledged for preparation of maps and related GIS. We also thank C. Sooriyabandara (Director General) and L. Peries (former Asst. Director Research) of the Department of Wildlife Conservation of Sri Lanka for providing permission for the survey. Finally, we thank the Asian Development Bank for providing the financial support. 


\section{Plate 58}

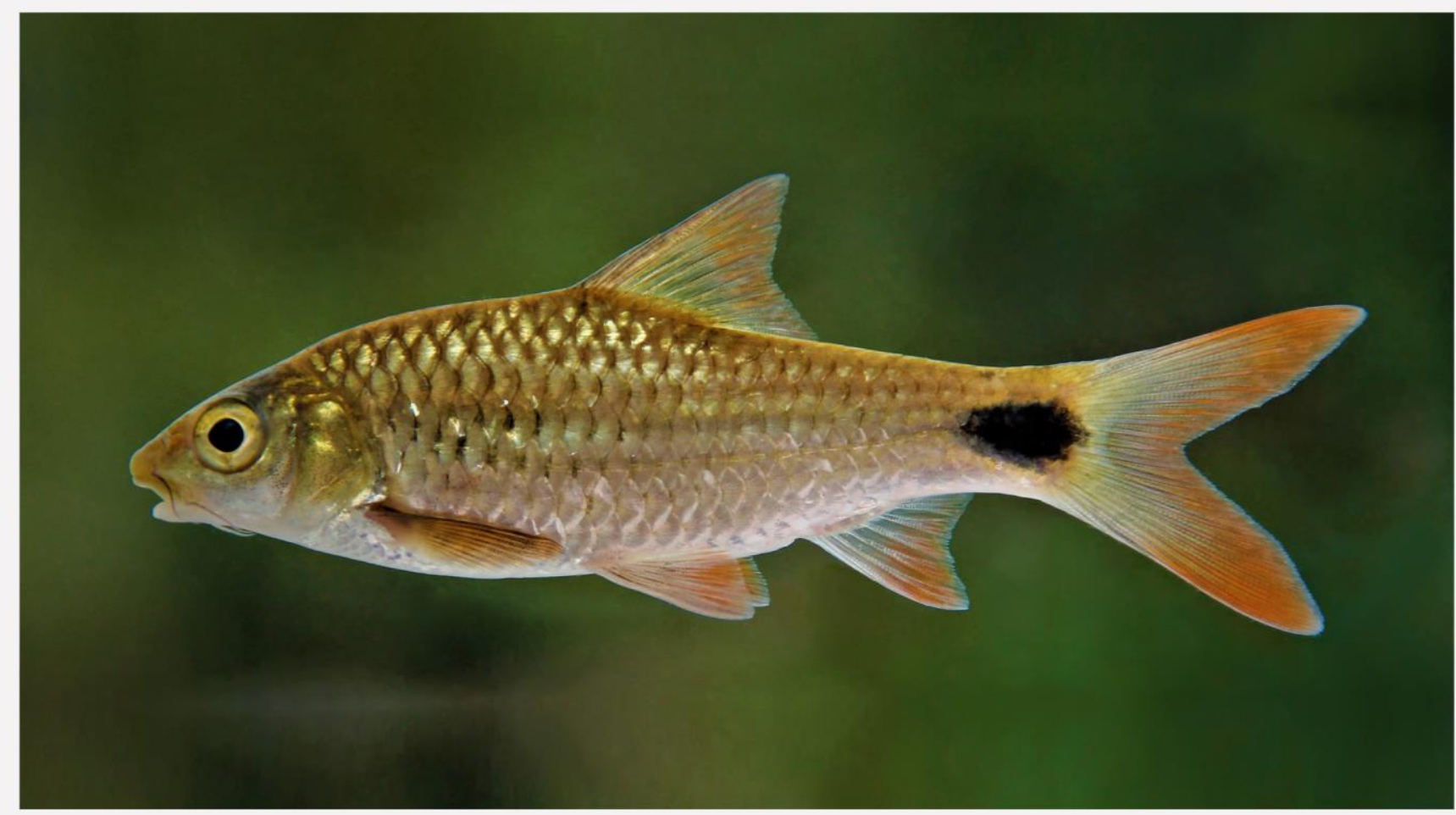

Figure 1. Martenstyn's barb, Systomus martenstyni; $\mathbb{C}$ Photo: S. de A Goonatilake

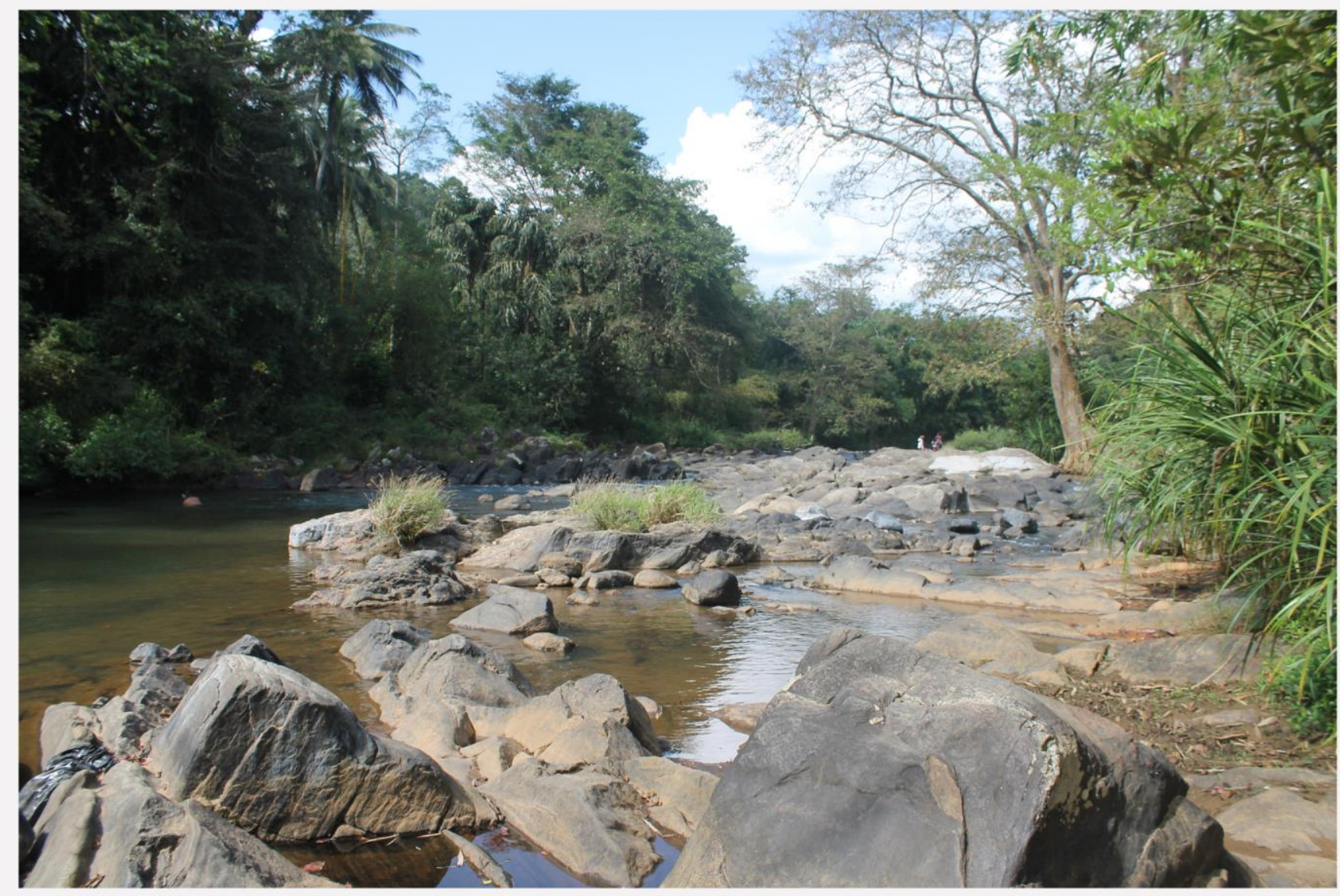

Figure 2. New location in Hulu Ganga near Giddawa, showing the typical habitat features reported for this fish; wide river with rocky pools and open and shaded areas; (C) photo: S. de A Goonatilake. 


\section{Plate 59}

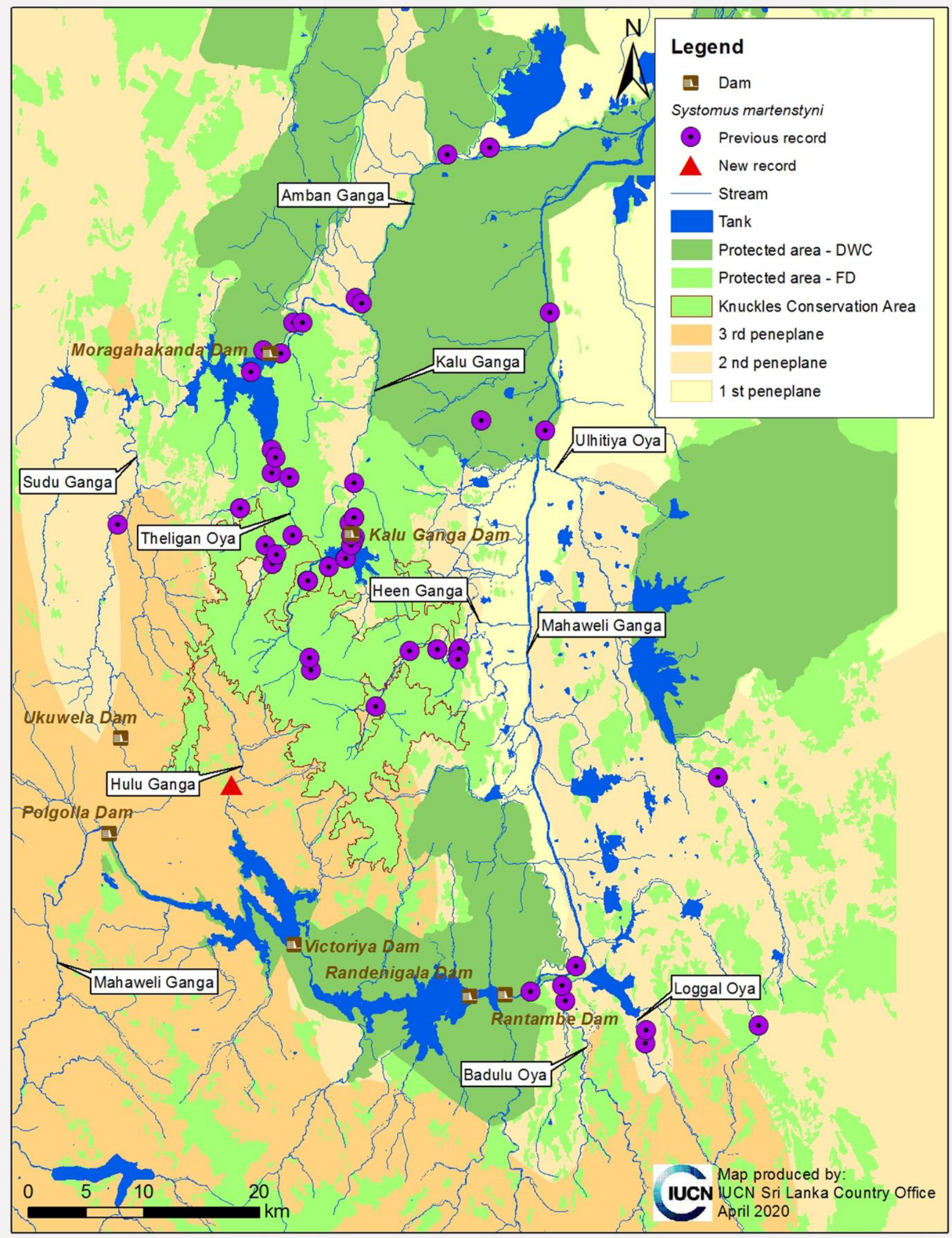

Figure 3. Current distribution of Systomus martenstyni. 


\section{Literature cited}

De Silva, M.A., N. Hapuarachchi, and T. Jayaratne (2015). Sri Lankan freshwater fishes. Wildlife Conservation Society, Galle: 391pp.

Fernando, M., O.W. Kotagama, and S. de A. Goonatilake (2019). Systomus martenstyni. The IUCN Red List of Threatened Species 2019: e.T18908A150838910. doi:10.2305/ IUCN.UK.2019-3.RLTS.T18908A150838910 .en. <downloaded on 31 January 2020>

Goonatilake, S. de A. (2012). The taxonomy and conservation status of the freshwater fishes in Sri Lanka. In: Weerakoon, D.K. and S. Wijesundara (eds.). The National Red List of Sri Lanka: conservation status of the fauna and flora. Ministry of Environment, Colombo: $77-80$.

Goonatilake, S. de A., M. Fernando, O.W. Kotagama, N, Perera, S. Vidanage, D. Weerakoon, A. Adam, and L. Maiz-Tome (2020). The National Red List of Sri Lanka: Assessment of the Threat Status of the Freshwater Fishes of Sri Lanka. In: Miththapala, S. (ed.). The National Red List of Sri Lanka. IUCN Sri Lanka and the Biodiversity Secretariat, Ministry of Environment \& Wildlife Resources: 106 pp.

IUCN-SL (2014). Implementation of the Biodiversity Action Plan of the Moragahakanda Agricultural Development Project and the Kalu Ganga Reservoir and Agricultural Extension Project. ENV /BD C $(\mathrm{M} \& \mathrm{~K}) /$ Consultancy 01-12. Ministry of Mahaweli Development, Sri Lanka: 234pp.
MPE-SL (2009). Feasibility Study for Expansion of Victoria Hydropower Station in Sri Lanka. Ministry of Power \& Energy, Ceylon Electricity Board of Sri Lanka: 88 pp.

Pethiyagoda, R. (1991). Fresh water fishes of Sri Lanka. The Wildlife Heritage Trust of Sri Lanka, Colombo: 362pp.

Pethiyagoda, R. M. Meegaskumbura, and K. Maduwage (2012). A synopsis of the South Asian fishes referred to Puntius (Pisces: Cyprinidae). Ichthyological Exploration of Freshwaters, 23 (1): 69-95.

Rajakaruna, S.L., G. Ellepola, T. Gunaratne, S. Madawala, and K. Ranawana (2015). Two new localities of the endangered fish Systomus martenstyni (Kottelat \& Pethiyagoda, 1991) (Teleostei: Cyprinidae) found in Sri Lanka. Check List, 11 (3): 1622.

Submitted: 25 June 2020, Accepted: 05 October 2020 Section Editor: Sujan Henkanaththegedara

O.W. Kotagama ${ }^{1}$, S. de A. Goonatilake ${ }^{1,3}$, W.P.N. Perera ${ }^{1} \&$ D.K. Weerakoon ${ }^{2}$

${ }^{1}$ IUCN Sri Lanka, 53 Horton Place, Colombo 07, Sri Lanka

${ }^{2}$ Department of Zoology, University of Colombo, Colombo 3, Sri Lanka ${ }^{3}$ E-mail: sampath.goonatilake@iucn.org

Published date: 28 November 2020 